\section{Effectiveness by Design: Overcoming Orientation and Transaction Related Barriers in Research-Industry Linkages}

\author{
Efetividade por Desenho: Superando as Barreiras Relacionadas à Orientação \\ e Transação na Interação Pesquisa-Indústria
}

\author{
Sergio Salles-Filho' $\odot$ \\ Adriana $\mathrm{Bin}^{2}$ - \\ Kleinsy Bonilla*1 0 \\ Fernando Antonio Basile Colugnati ${ }^{3}$
}

\section{ABSTRACT}

Context: dynamic and productive linkages between research organizations (ROs) and industry are actively spurred in advanced nations. Conversely, Latin American countries face significant challenges in fostering researchindustry interactions. Solid models of research-industry cooperation are of particular interest to emerging economies such as Brazil. Objective: this article aims at presenting a comprehensive study of the Brazilian Agency for Industrial Research and Innovation - Embrapii, an entity focused on addressing barriers to cooperation between research ROs and companies. Methods: data from 63 projects supported by Embrapii involving three ROs and 44 companies was collected employing four sources of primary data: two web questionnaires, interviews and technical visits. The scope of the study is based on Embrapii's initial phase carried out during 20122016. Results: findings revealed that specificities of the model allow the emergence of conditions for effective research-industry cooperation. Conclusion: The Embrapii's model contributed to overcoming both orientation-related and transaction-related barriers, resulting in positive outcomes. Expected technological results such as new products, processes, and methodologies, were achieved in the majority of projects.

Keywords: STI policy; Latin America; Brazil; research-industry cooperation; innovation instruments.

\footnotetext{
* Corresponding Author.

1. Universidade Estadual de Campinas, Instituto de Geociências, Departamento de Política Científica e Tecnológica, Campinas, SP, Brazil.

2. Universidade Estadual de Campinas, Faculdade de Ciências Aplicadas, Limeira, SP, Brazil.

3. Universidade Federal de Juiz de Fora, Programa de Pós-Graduação em Saúde, Juiz de Fora, MG, Brazil. Cite as: Salles-Filho, S., Bin, A., Bonilla, K., \& Colugnati, F. A. B. (2021). Effectiveness by design: Overcoming orientation and transaction related barriers in research-industry linkages. Revista de Administração Contemporânea, 25(5), e190346. https://doi.org/10.1590/1982-7849rac2021 190346.en
}

\section{RESUMO}

Contexto: observa-se atualmente grande estímulo ao estabelecimento de interaçóes entre organizaçóes de pesquisa e indústria em países desenvolvidos. Em países da América Latina, este estímulo é acompanhado de desafios significativos. Países emergentes como é o caso do Brasil, tem particular interesse em conhecer e implementar modelos efetivos de interação pesquisa-indústria. Objetivo: Este trabalho apresenta um estudo da Empresa Brasileira de Pesquisa e Inovação Industrial - Embrapii, uma entidade orientada ao fomento de relaçôes entre organizações de pesquisa e empresas. Métodos: a pesquisa envolveu a coleta de dados de 63 projetos apoiados pela Embrapii durante sua fase piloto (entre 2012 e 2016) envolvendo três organizaçóes de pesquisa e 44 empresas. Foram empregados quatro instrumentos de coleta de dados: dois questionários, entrevistas e visitas técnicas. Resultados: achados da pesquisa indicaram que as especificidades do modelo Embrapii permitiram a emergência de condiçóes para uma interação pesquisa-indústria efetiva. Conclusáo: o modelo Embrapii contribuiu para a superação de barreiras de orientação e de transação na interaçáo pesquisa-indústria, apresentando bons resultados. Efeitos na geração de novas tecnologias, como novos produtos, processos e metodologias foram alcançados na maioria dos projetos.

Palavras-chave: políticas CTI; América Latina; Brasil; interação pesquisa-indústria; instrumentos de inovação.

JEL Code: N16, P13, O32

Editor-in-chief: Wesley Mendes-da-Silva (Fundação Getulio Vargas, EAESP, Brazil) (C) Reviewers: Renata Lèbre La Rovere (Universidade Federal do Rio de Janeiro, Brazil) (i) Gilberto Perez (Universidade Presbiteriana Mackenzie, Brazil) (0) Peer Review Report: The Peer Review Report is available at this external URL.

Received: October 18, 2019 Last version received: September 05, 2020 Accepted: September 10, 2020

\# of invited reviewers until the decision:

\begin{tabular}{|c|c|c|c|c|c|c|c|c|c|c|}
\hline & 1 & 2 & 3 & 4 & 5 & 6 & 7 & 8 & 9 & 10 \\
\hline $1^{\text {st }}$ round & (x) & (x) & (x) & (x) & (x) & $x$ & (x) & $x$ & 2 & $\stackrel{9}{2}$ \\
\hline $2^{\text {nd }}$ round & 2 & 2 & & & & & & & & \\
\hline $3^{\text {rd }}$ round & 2 & & & & & & & & & \\
\hline $4^{\text {th }}$ round & $\stackrel{9}{2}$ & & & & & & & & & \\
\hline
\end{tabular}




\section{INTRODUCTION}

Innovation has progressively become a critical determinant of competitiveness, economic growth, and national progress. Understood in its four edges product, process, marketing, and organization innovation - (Organization for Economic Co-Operation and Development [OECD], 2019), the goal of fostering innovation occupies different roles in the economic development agendas of countries. One of the main issues regarding the practice of innovation and research policies is the significance and effects of interactions between actors involved in innovation systems, mainly research organizations - ROs (in this article, ROs is a generic term to identify universities, and public and private not-forprofit research organizations), companies and governments.

Several reasons justify the importance of getting stronger links between ROs and companies (Cohen, Nelson, \& Walsh, 2002; Etzkowitz, 1998). Generally speaking, companies collaborate with ROs in order to access leading-edge research knowledge, research infrastructures, or research services to complement in-house capabilities, to identify potential future employees, and to take advantage of networking effects (Dietz \& Bozeman, 2005; Schaeffer, Ruffoni, \& Puffal, 2015).

Conversely, ROs collaborate with firms to access industrial capabilities and resources, to commercialize research ideas or test their commercial potential, to develop real-world links and build experience or to develop potential career pathways for their professionals (Caloghirou, Tsakanikas, \& Vonortas, 2001; Cohen et al., 2002; Etzkowitz, 1998; Fischer, Schaeffer, Vonortas, \& Queiroz, 2017).

Although common requirements do exist for the promotion of RO-industry linkages, specificities are always present. It is well known that the degree of maturity and interconnection between agents of innovation systems in all levels - national, regional, or sectoral - interfere in the effectiveness of policies that are headed to promote such linkages. This is particularly important to take into account in less developed countries - and emerging economies as conditions fostering or precluding linkages.

Some authors argue that in these countries the mismatch between research - mainly carried at public ROs - and companies is particularly evident (Arza, 2010; Dutrénit \& Arza, 2010; Fernandes et al., 2010; Suzigan, Albuquerque, García, \& Rapini, 2009; Vaaland \& Ishengoma, 2016), while others argue that this cannot be taken for granted since there is not enough evidence to sustain such proposition (Cruz, 2019; Pinho \& Fernandes, 2015). Therefore, there is a pressing need to create and validate indicators and measurements to better understand $\mathrm{RO}$ industry linkages in those countries.

Some questions need further attention to setting the appropriate conditions for RO-industry linkages to thrive in this context. What are the policy features that contribute more to a successful implementation of RO-industry linkages in a particular socio-economic environment such as those of less developed or emerging countries? What are the requirements of policy beneficiaries to support the implementation of such policies? The primary issue here is to understand the barriers of RO-industry linkages and assess how a specific combination of policy design and implementation can help to overcome those barriers.

The purpose of this paper is to analyze the effectiveness of a recent policy model conceived to foster cooperation between ROs and companies in Brazil. This policy model came along with the creation of the Brazilian Agency for Industrial Research and Innovation (Embrapii), which can be understood as an institutional innovation within the national framework of Science, Technology, and Innovation (STI). Secondary objectives include both a better understanding of factors that hinder or facilitate RO - industry collaboration and an assessment of Embrapii's model focusing on its initial phase carried out from 2012 to 2016 .

A total of 63 projects supported by Embrapii involving three ROs and 44 companies were evaluated employing four sources of primary data: two web questionnaires applied to project leaders in ROs and companies, interviews carried out with principal managers of the recipient ROs, and interviews and technical visits carried out by experts in the projects' primary areas of knowledge with project leaders, both in ROs and companies.

Having in perspective some robust and well-known innovation policy instruments and narrowing it down to contextualize the Brazilian experience of Embrapii pilot phase, this work provides a better understanding of the design, characteristics, and potential impact of Embrapii, not only from the traditional perspective of technology transfer toward the industrial sector, but also from the development of complementary competencies within the research organizations and companies (industry and service-oriented) in cooperation for research and innovation. Findings show evidence that the specificities of the Embrapii's model allow the emergence of conditions for effective paths for research-industry cooperation in Brazil.

After this introductory section, the article is structured as follows: the section of Literature Review addresses influencing scholarly works about the challenges, barriers, obstacles, and policies involving research-industry cooperation; particular attention is devoted to the Brazilian 
case. The next section presents the sample, variables of interest, and procedures for data collection and analysis. Empirical results and discussion are provided in following section. Closing, the final section presents the final remarks, implications, and avenues for future research.

\section{LITERATURE REVIEW}

The issue of how to foster linkages between ROs and companies has become a core issue in the field of STI policy debate. More intensely, the last 20 years have seen a proliferation of literature addressing the rationale, benefits, and hindrances affecting such linkages. This section focuses on the obstacles and difficulties in bridging technological and scientific research with industry applications (Brunneel, D'Este, \& Salter, 2010; Filippetti \& Savona, 2017; Freitas, Marques, \& Silva, 2013; Kaufmann \& Tödtling, 2001; Muscio \& Vallanti, 2014; Tartari \& Breschi, 2012), and how different policies and policy instruments have attempted to reduce and overcome such obstacles.

ROs-industry linkages, as a partnership, have been defined by Hagedoorn, Link, and Vonortas (2000) as an innovation-based relationship, a cooperative nexus in which partners involved aim at unraveling innovation outcomes. The Oslo Manual (OECD, 2019) defines innovation as a "new or improved product or process (or a combination thereof) that differs significantly from the unit's previous products or processes and [that] has been made available to potential users (product) or brought into use by the unit (process)" (OECD, 2019, p. 49). Such a definition depicts the complexity and deep entanglement of the concept, which is particularly challenging when it involves a diverse group of actors and their interactions.

Several authors have devoted considerable efforts to test the traditional Schumpeterian analysis, as well as arguing that innovation is not linear, but rather a collaborative process that benefits from interactions amongst agents from diverse environments (Borrás \& Edquist, 2013; Cunningham \& Gök, 2012; Etzkowitz \& Leydesdorff, 2000; Kaufmann \& Tödtling, 2001; Wilson, 2012). In this regard, partnerships are an intrinsic component of the innovation process.

Kaufmann and Tödtling (2001) argue that the interaction of firms with scientific and technological research organizations stimulates industry innovativeness, enabling companies to access a diverse range of knowledge. A critical element in their approach is the maintenance of a systemic diversity in order to improve the innovative performance of the firms involved.

In this sense, innovation, or at least the creation of knowledge and skills that can culminate or contribute to this process, must be understood as the preferred outcome of ROs-industry linkages, and therefore an indicator of its success and desired performance from the partners.

\section{Barriers and obstacles to successful research-industry cooperation}

In recent literature, different typologies have been proposed to assess limitations experienced in the cooperative relations between $\mathrm{ROs}$ and companies. Bruneel, D'Este, and Salter (2010) sustain that collaboration between industry and a university faces various constraints. They propose examining such limitations in two categories: first, barriers related to differences in the orientation of industry and universities, described as 'orientationrelated barriers.' Second, barriers related to the conflicts over intellectual property and dealing with university administration described as 'transaction-related barriers.' These barriers may limit the depth and quality of interactions between universities and businesses, with transaction-related barriers being more challenging to address.

Obstacles and barriers are brought by all parties; they can come from the firms, ROs, and third parties. Tartari and Breschi (2012) focus on the costs perceived by academics, scientists, and researchers. They understand that collaborating with industry constitutes a discretionary behavior for academics, consequently affecting the success or failure of university-industry collaborative relations. As stated by Etzkowitz and Zhou (2008), "transition to another academic format (entrepreneurship) is rarely a smooth process. It is typically accompanied by controversy, acrimony and debate" (Etzkowitz \& Zhou, 2008, p. 632)

This is consistent with the proposed by Muscio and Vallanti (2014) using a scale to consider 16 obstacles arising from the academic/science perspective divided into four categories: conflicts with companies, networking problems, conflicts with academic goals, and the distance between academic research and business needs.

Meanwhile, Filippetti and Savona (2017) present a discussion from the company's perspective. Their analysis focuses on the firm's barriers to cooperation with public research institutions, stating an array of deterrents - not very different from those above cited and that can also be categorized into orientation and transaction-related barriers - that vary depending on the sector of the industry.

Simachev, Kuzyk, and Feygina (2014) enlist common obstacles to cooperative relations between $\mathrm{ROs}$ and companies from the perspective of the latter. Four obstacles stand out: lack of clear procedures and bureaucracy in ROs, insufficient orientation at company needs, the incongruence of developments' quality and company needs, and weak orientation of research organizations at customer needs. 
It is not difficult to group these sorts of obstacles in the two categories of barriers proposed by Bruneel et al. (2010): obstacles of orientation stand for the alignment of the needs and expectations from both sides (it is not a matter of eliminating differences over orientations, but to make them more mutually fed); transaction accounts for the contractual and operational obstacles that make relations more or less frictional.

In other words, transaction-related and orientationrelated barriers, as proposed by these authors, may be considered as two complementary categories of barriers influencing partnerships, both by RO's and company's perspective. These two categories of limitations may be taken as a synthesis of the vast diversity of obstacles discussed in the specialized literature.

At this point, it becomes relevant to discuss how policy and policy instruments aiming at fostering ROsindustry cooperation in the process of innovation have addressed or should address the obstacles mentioned above.

\section{Policy and policy instruments aiming at fostering ROs-industry links}

Public policy may influence the propensity of firms and ROs to cooperate to trigger the beneficial results of such interactions. This presents to policymakers a challenging and constant question of what would be the most appropriate approach to promoting ROs-industry collaboration. In other words, the question is: What policies and policy instruments would be more effective in dealing with the barriers of orientation and transaction mentioned in the previous section to develop new technologies and promote innovation in a broad sense?

The design of policy priorities and the selection of policy instruments is a critical decision when aiming at addressing the identified problems. There are no formulas, or infallible prescriptions, as sustained by Borrás and Edquist (2013): "strictly speaking each policy instrument used by a government or public agency is unique" (Borrás \& Edquist, 2013, p. 1515). Mazzoleni and Nelson (2007) complement sustaining that successful public research programs of other countries can, and should, serve as broad guides for countries trying to establish their own programs but as indicators of principles to follow, not as templates.

Among the instruments used in public policy to overcome challenges and barriers to research-industry cooperation, Borrás and Edquist (2013) present a three-fold typology: regulatory instruments, economic transfers, and soft-instruments. Regardless of the choice of instruments, they argue that the design of innovation policy must include explicit purposes and objectives, identifying the problems the policy shall address, as they cannot be solved by the research organizations, neither by the firms without the policy intervention. With this in mind, it is clear that the analysis of barriers to the industry-research cooperation requires close consideration of the context, and as a consequence, the characteristics and content of the public policy and policy instruments to address such obstacles differ amongst countries or even localities because of their particular ecosystems of innovation.

Cunningham and Gök (2012) propose a set of general lessons for the design and implementation of research-industry collaborative support policy instruments. They regard long-term vision and stable commitment of government funding as one of the most successful measures. They also remark the importance of a clear understanding of the motivations for the partners to participate in the collaborative relationship, which would require the definition of a clear purpose for the intervention in advance. This raises their concern about orientation-related barriers to RO-company linkages policy design.

Veletanlić and Sá (2019), analyzing ROs-industry collaboration in two Canadian programs, also refer to a common orientation-related barrier: the prioritization made at the level of policy design does not match partners' interests. "Our analysis points to misalignments at the microand meso-levels between the ideas driving the programs and the incentives at play for academic researchers and industry partners, which culminate in the displacement of macrolevel policy goals" (Veletanlić \& Sá, 2019, p. 110). In other words, these authors found evidence that the "programmatic ideas guiding university-industry programs did not reflect the reality of Canadian firms' limited engagement in R\&D" (Veletanlić \& Sá, 2019, p. 113). An immediate consequence of these 'internal' misalignments is the necessity of employing indicators able to identify concrete and specific motivations for involved parties in order to achieve the success of policy implementation.

Kroll (2016) presented a study of experiences from various developed countries (Germany, United States, United Kingdom, France, Finland, and Norway) consisting of initiatives of long-term strategic partnerships for scienceindustry collaboration. The author aimed at finding common characteristics and lessons despite different country contexts. Kroll (2016) highlighted some critical elements; among them, it is worth mentioning: the importance of complementary role among the partners in which actors share a common perception of future challenges and opportunities combined with the willingness to invest. Once more, the orientation driver figures as a central proposition.

In addition to the perspectives of the authors mentioned above who considered orientation-related 
barriers as an essential issue for policy design to deal with, other authors focus their concern on transaction-related barriers.

Cunningham and Link (2015) examined the process of fostering university-industry research and development collaboration in the European Union countries, addressing cross-country differences with special attention on the characteristics of the national innovation systems. Structural elements, as for regulatory harmonization within countries' institutions, intellectual property protocols, standardized agreements, and templates, are seen as central to facilitate interaction between universities and businesses.

An illustrative case is what has been experienced in China. According to Teng (2010), the need for greater university-enterprise collaboration and research commercialization is hampered by several constraints including, among others,

"the dominance of foreign investments in the critical sectors of manufacturing; lack of effective $R \& D$ funding in the industry; lack of highly capable scientists who can lead in terms of knowledge frontiers, lack of innovative entrepreneurship; and focus of universities toward teaching thus creating a divergence of objectives between university and industry" (Teng, 2010, p. 298).

In the past few years, China has experienced essential shifts in its STI position, particularly in terms of university-industry collaboration. Zhou, Tijssen, and Leydesdorff (2016) and Cheng, Zhang, Huang and Liao (2018) have presented a path of increasing collaboration. Although with limited effects over scientific production (Zhou, Tijssen, \& Leydesdorff, 2016), collaborations have mainly resulted in technology production, which is expected in this kind of effort. Cheng et al. (2018) emphasize that university-industry collaboration has been driven by industry in the prevalence of problem-oriented projects, reducing potential orientation-related but, also, transactionrelated barriers.

Another critical issue raised in this matter relates to the participating entities' characteristics since they can determine the viability of their performance in the partnership. Therefore, Cunningham and Gök (2012) recommend matching partners with tracked records of collaboration with new partners, which means relating experienced organizations with newcomers, in addition to building a sense of belonging to the process through a strong and positive brand, and the image is likely to increase further networking and to lower transaction barriers.

Other authors such as Bruneel et al. (2010) and Steinmo and Rasmussen (2018) also reinforce the experience of collaboration as a factor that can help to mitigate barriers. The first mention the breadth of interaction channels and inter-organizational trust, while the latter discusses social capital - shared goals, shared cultures, mutual respect and trust, relational closeness, expectations, and reputations as necessary to overcome barriers. Other authors, such as Cullen, Johnson, and Sakano (2000) and Ahuja (2000), had previously discussed commitment, trust, and social capital as essential elements of partnerships between firms. The attention to this 'soft side' of collaboration agreements can be easily applied to the RO-industry collaboration. Although these elements can be treated as strategic choices of the actors interested in cooperation, they can also be considered in the design of policies, as it will be seen below in the discussion of the Embrapii case.

Sá and Litwin (2011) examined Canada's case and the policy instruments employed by the federal government to stimulate university-industry linkages. Key features in the Canadian experience are the diversification of the policy mix over the last 20 years and a marked shift from stimulating short-term interactions to long-range strategic relationships. This is also a signal of the need for stimulation commitment between partners in policy design.

Radosevic (2011) analyzed the factors behind recurrent policy failure to support science-industry linkages in Central and Eastern Europe as well as the Commonwealth of Independent States. Transition economies require specific conditions at the micro and medium level of technologybased competition, both for internal and international markets. Accordingly, he supports the importance of policy experimentation based on a thorough understanding of local context instead of "an uncritical application of conventional policy in the context of catching up and laggard economies" (Radosevic, 2011, p. 378).

\section{Policy and policy instruments aiming at fostering ROs-industry links in Latin America and Brazil}

Freitas, Marques and Silva (2013) and Guimón (2013) sustain that developing countries may face even higher barriers to establish collaboration between academia and industry. Experiences from Latin American (LA) countries in general and Brazil, in particular, offer additional insights (Arocena \& Sutz, 2003; Dutrénit \& Arza, 2010; Ferreira \& Ramos, 2015; Fischer et al., 2017; Schaeffer et al., 2015). Dutrénit and Arza (2010) provide some evidence that interactions between ROs and industry, although still weak for international standards, have increased since the turn to the new millennium, mainly as a consequence of policy changes that followed the emergence of intellectual 
and political discussions on the benefits of promoting ROsindustry interactions.

In more recent work, Confraria and Vargas (2019) reassure that "on average, Latin American countries have been reducing the gap with the world-leading regions" (Confraria \& Vargas, 2019, p. 874), on this matter and that policies that promote science-industry linkages in those countries have received positive evaluations. However, the magnitude of such policies is still too modest to pull LA countries toward knowledge-based economies.

The persistent difficulties in those countries reflect mainly the aspects of divergent interests (orientation) and institutional factors (transaction). Issues such as university bureaucracy, project duration, differences in the level of knowledge, and definition of property and patent rights are frequently mentioned. These are typically transaction and orientation barriers as shown by Dutrénit and Arza (2010), who focus on Latin America, and by Albuquerque, Suzigan, Kruss, and Lee (2015), with a study carried in twelve countries.

Similar findings have been pointed out for the Brazilian case (Albuquerque, Suzigan, Kruss, \& Lee, 2015; Cruz, 2019; Fernandes et al., 2010; Rapini et al., 2009; Rocha, Lima, Lameira, \& Quelhas, 2012; Schaeffer et al., 2015; Suzigan et al., 2009).

Studying linkages between public research organizations (PRO) and companies in Brazil, Fernandes et al. (2010) found higher mutual benefits when the relations were based on technical services provided by PRO than on investments in $\mathrm{R} \& \mathrm{D}$. According to Fernandes et al. (2010), this is not surprising for 'immature National Systems of Innovation.'

\section{Pinho and Fernandes (2015) observe that}

"technological demand of firms to universities in developing countries is different from that experienced in developed countries, but not necessarily weaker or less relevant. Usually, the relationship is not concerned with innovation in a strict sense, but with adaptation, improvement, incremental change, and adjustments to local conditions" (Pinho \& Fernandes, 2015, p. 162).

Fostering the ROs-industry linkages is not a new target of public policies in the Brazilian context. The pursuit of more efficient and effective instruments to stimulate those linkages is a sort of endless search. Salles-Filho (2002, 2003a, 2003b) has shown that since the 1970's STI policies in that country have been formally oriented by the so-called necessity of closing the gap between knowledge production at $\mathrm{RO}$ and knowledge use in industry and agriculture.
Despite an explicit intent of policies in the past years to promote RO-industry linkages, the analysis of the effectiveness of policy instruments - mainly related to capacity building, technology development, and innovation — is a more recent endeavor (Albuquerque et al., 2015; Fischer et al., 2017; Garcia, Araujo, Mascarini, Santos, \& Costa, 2014; Pacheco, 2019; Silva Neto et al., 2013; Suzigan et al., 2009; Terra, Batista, Campos, \& Almeida, 2013).

Looking at the main policies implemented after the Law of Innovation (Law 10973/2004) (and even before), Negri and Rauen (2018), Pacheco (2019), and Zuniga, Negri, Dutz, Pilat and Rauen (2016) analyze the evolution of STI policies in Brazil showing that incentives to foster innovation and ROs linkages have been based on direct and indirect financial support for companies, such as tax breaks, subvention (direct non-reimbursable funding), and to mention the most important, credit equalization.

It is essential to distinguish two major categories of the policies' instruments for companies: those focused on lowering the costs of investment (credit, subvention, and some fiscal incentives as Law 11196/2005); and those based on obligations of STI investments as a requisite to access the policy (sectoral fiscal incentives as for information and communication technologies and automobile ones, and regulated sectors as oil and gas and electricity).

Within these two categories, some instruments impose obligations for cooperation with ROs (oil and gas and fiscal incentives for the ICT sector) or are firmly structured upon cooperation with ROs (electricity). However, in none of these cases policies' instruments state any guidelines to tackle barriers of orientation and transaction. The only requirement is to establish cooperation, sometimes just hiring research in ROs, or sometimes making real interactions. Policies have not been focused on other barriers beyond the financial ones. The general assumption has been that of the financial wall faced by firms to innovate, with or without cooperation.

Nobody denies the importance of lowering the 'cost of the money' for companies to invest in innovation and to establish ROs linkages. This has been of critical importance in the Brazilian economy, whose interest rates have been placed amongst the highest worldwide in the past two decades. However, what became clear for the time being is the observable fact that this has not been enough to leverage investments in innovation and particularly in establishing RO-industry linkages.

Several STI policy evaluation studies have found a low degree of effectiveness of the policies to foster innovation in companies, neither lowering the cost of money nor obliging them to invest in innovation through enforcement. Negri and Rauen (2018) present a list of studies evaluating STI policies in Brazil. Mainly those based on fiscal incentives 
and subsidized credit have not presented critical positive effects on the level of the companies' investment in R\&D and innovation.

Data from the Brazilian Survey of Innovation Pintec (Instituto Brasileiro de Geografia e Estatística [IBGE], 2020) shows a relative stagnation of leading indicators in the past four triennial surveys (2006-8; 2008-11; 2012-14; and 2015-17). For the purpose of this article, it is particularly relevant to highlight variables as for the percentage of firms that innovate $(38 \% ; 35.7 \%$; $36 \%$; and $33.6 \%$, respectively for the four periods), and the percentage of companies that innovated having cooperation with ROs $(4 \% ; 6 \% ; 6 \%$; and $5 \%$, respectively for the four periods) (IBGE, 2020). In the same period, Brazil drop from rank 40 to rank 69 in the Global Innovation Index (Negri \& Rauen, 2018).

Policies have also funded research organizations through non-reimbursable funds in order to promote cooperation with companies, stimulating technology transfer, R\&D projects, and specialized services to firms (Albuquerque et al., 2015; Pacheco, 2019; Pinho \& Fernandes, 2015). As shown by Zuniga et al. (2016) and Negri and Rauen (2018), the biggest share of public funds to promote $\mathrm{R} \& \mathrm{D}$ and innovation (more than $60 \%$ ) has been allocated directly to ROs, being the objective of promoting cooperation with companies an important sub-share of that percentage.

In spite of an observable soar in joint cooperation as discussed by Albuquerque et al. (2015) and Pinho and Fernandes (2015), and in collaborative scientific publications between companies and ROs (Cruz, 2019), many authors have unveiled low results in terms of technology development and appropriation by companies and still less in terms of innovation. This is not only related to RO-I linkages, but also from company's in-house efforts (Negri \& Rauen, 2018; Pacheco, 2019).

As discussed by Rauen and Turchi (2017), ROs in Brazil face important juridical and bureaucratic limitations to cooperate with companies. Authors highlight legal and cultural hindrances that raise juridical and political uncertainties that have not being properly addressed in the Brazilian legal framework, although efforts in introducing new legislation - as the Innovation Law - to remove legal, infra-legal, and political risks associated to RO-I cooperation.

Taking all of these aspects into consideration, it is possible to affirm that the 'theory of change' underneath those policies' instruments can be attributed to a general assumption that the main barrier to be removed to foster innovation and $\mathrm{ROs}$ linkages had a financial nature. Giving subsidized money, non-reimbursable funds, and fiscal incentives for companies with one hand and non- reimbursable funds for ROs with another hand to incentivize them to approach companies. Consequently, policies assumed that companies would increase their investments in innovation once this barrier is reduced, both alone and in cooperation with research organizations. Unfortunately, what can be called the 'financial drive' of STI policies has not achieved much effectiveness, as evaluations have shown.

Various authors (Fernandes et al., 2010; Negri \& Cavalcante, 2014; Pacheco, Bonacelli, \& Foss, 2017; Rapini et al., 2009) refer to structural conditions in the Brazilian innovation system that need more than financial support. Other challenges include the lack of competition and the focus on the internal market; high level of transaction costs related to the regulatory framework; and the complex bureaucratic environment for entrepreneurship.

This means that, with a few exceptions, policies have not addressed orientation and transaction-related barriers. They mostly focus on the cost of the money and the cost of opportunity, reducing it throughout different sorts of subsidies, leaving aside other structural factors related to orientation-related and transaction-related barriers.

Of course, there have been some exceptions. It is worth mentioning the program Partnership for Technological Innovation (Pite) running since 1995 by the São Paulo Research Foundation (Fapesp). This program fosters cooperation between $\mathrm{ROs}$ and companies through a matching fund mechanism, usually in a 50/50 base. It supposes companies will predefine and align their priorities with ROs (and vice-versa) and adjust operational and contractual steps in order to lower barriers of orientation and transaction. However, as we are going to see further in this article, it is slight — but not negligibly — different of the Embrapii's case since the Pite program does not introduce specific requirements to incentive orientation and transaction factors.

\section{STUDY BACKGROUND: THE CASE OF EMBRAPII}

The Brazilian Agency for Industrial Research and Innovation - Embrapii was created in 2011, envisioning research-industry strategic alliances to contribute to innovation in the Brazilian industry. It was conceived under the partnership among the Ministry of Science, Technology, Innovation, and Communication, the Ministry of Education, the National Confederation of Industry (CNI), and the Brazilian Innovation Agency (Finep). Embrapii has a novel management model (Azevedo et al., 2016; Toledo, Castro, \& Gilaberte, 2017), whose rationale is to influence the relationship and enhance interactions between ROs and companies, sharing costs and risks and aiming technological 
innovation in pre-competitive stages (Empresa Brasileira de Pesquisa e Inovação Industrial [EMBRAPII], 2018).

Two main mechanisms are guiding the operation of Embrapii. The first is the accreditation of existing ROs' laboratories based on the analysis of a long-term action plan and RO's historically developed competences. The accreditation process occurs through competitive public calls, periodically organized by Embrapii. Several calls have been released until the beginning of 2020, resulting in 55 accredited units or labs up to middle 2020 .

Once the accreditation process is finalized, the accredited labs initiate the accomplishment of action plans through partnerships with firms. Embrapii non-reimbursable resources represent up to $1 / 3$ of the total value of the project portfolio contracted by each $\mathrm{RO}$; the remaining $2 / 3$ should be negotiated between $\mathrm{ROs}$ - financial and non-financial resources - and partner companies - exclusively financial contributions for the latter.

The second mechanism guiding the operation of Embrapii is the monitoring of action plans and project execution. From 2014 to 2019, Embrapii invested approximately USD 105 million in collaboration projects (Empresa Brasileira de Pesquisa e Inovação Industrial [EMBRAPII], 2019). As pointed by Goulart (2012), the model was created as a mechanism to articulate efforts of research, development, and innovation in a less fragmented and isolated manner than historically done in the country.

Projects from Embrapii's pilot phase, which is the focus of this article, were executed from 2012 to 2016. The pilot phase was not based on a public call. It involved the selection of three ROs: the federal National Institute of Technology (INT), the São Paulo state-owned Institute for Technological Research (IPT), and the private non-profit Manufacturing and Technology Integrated Campus (Senai Cimatec). In 2015, Embrapii hired an evaluation of its pilot phase as a way to understand if the expected results were achieved and to create the inputs for its institutional evaluation model. In the next section, the methodology employed in the evaluation is presented, as well as the pilot phase's main features.

\section{METHODOLOGICAL PROCEDURES}

The evaluation of the Embrapii's pilot phase was oriented to measure if and to what extent this particular policy model was designed and implemented to overcome well-known barriers to ROs-industry linkages. In this sense, the evaluation focused both on (a) the behavioral and procedural changes of involved actors, focusing on governance, prospection of partnerships, negotiation among organizations, project management, and project execution (tackling orientation and transaction barriers), and (b) the outputs and outcomes of the R\&D and innovation projects (technological results and its appropriation).

The methodological approach focused on the additionality of behavior, outputs and outcomes, tracking down the changes that occurred between the baseline $\mathrm{T} 0$ and the end of Embrapii's pilot phase T1 in different variables. As a pilot phase with no similar condition in the national context, given the short period of project execution (20122016), it was not employed a control group. However, it was employed as a proxy of counterfactual a 'redundant causality factor' (Salles-Filho, Avila, Alonso, \& Colugnati, 2010; Salles-Filho, Bonacelli, Carneiro, Castro, \& Santos, 2011). The redundant causality factor, also called alphafactor $(\alpha)$, is an alternative for approaching causality. Every measurement obtained for a given variable $a$ is (re) confirmed using a redundant causality factor $\alpha$ within a scale of 0 to 1 . Equation (1) summarizes how this factor operates in practice to calculate impact $I i j$.

$$
I_{i j}=g_{i j} \times \Delta\left(a_{i j}\right) \times \alpha_{i j}
$$

where $g_{i j}$ represents the direction of the observed variation [-1, 1] or the absence of variation, $\Delta\left(a_{i j}\right)$ represents the difference between T1 and T0 for a given variable $a$ (additionality), and $\alpha_{i j}$ represents the redundant causality factor [0-1].

\section{Sample}

The evaluation focused on the 63 projects successfully executed in the pilot phase by the three ROs in cooperation with 44 companies, considering that some companies had more than one project. The distribution of projects by ROs was the following: 30 developed by the RO Cimatec totalizing an amount of U\$32.2 million; 20 developed by IPT totalizing U\$ 15.7 million; and 13 by INT totalizing U\$ 5.8 million.

These amounts included financial resources from Embrapii and companies. The total costs of projects are higher because they include economic non-financial counterpart from ROs. As mentioned, the total economic cost of a typical Embrapii's project is shared on a 1/3 base per partner: company, RO, and Embrapii. The varied sectoral distribution of partner companies (according to the National Classification of Economic Activities - Cnae) is presented in Table 1 (some companies were classified in more than one sector).

\section{Data collection and data analysis}

Data collection was done through four different instruments: (I1) web survey applied to project coordinators 
in $\mathrm{ROs}$, focusing on project's results and institutional managerial changes (the latter in the context of behavioral additionality); (I2) web survey answered by the one responsible for projects in companies, focusing on project development, outputs, and the level of satisfaction from the company perspective; (I3) semi-structured face-toface interviews conducted by five experts with project coordinators at ROs and companies, focusing on project results from a technical perspective; and (I4) open face-toface interviews with the board of directors of ROs carried out by the team of evaluators, focusing on the institutional and organizational impacts of Embrapii's model over the three organizations. Regarding I3, experts visited and interviewed responsible people for a sample of 25 projects after surveys I1 and I 2 have been completed. Data collection was conducted between October 2015 and April 2016, beginning with
I4, followed by I1 and I2 and finally I3. A summary of these methodological procedures and the response rates are presented in Table 2. All indicators employed in the evaluation through I1, I2, and I3 instruments are presented in Appendix I (Table A1).

All but the I4 instrument of data collection was pre-tested with a sample of respondents. The triangulation strategy through the application of different types of data collection instruments orientated to different respondents allowed the collection of diverse data about the outputs, outcomes, and behavioral changes, and also the consideration of distinct perspectives regarding the selected variables. This was critical to guarantee the validity of research findings, since there was more than one source of information to the same variable.

Table 1. Economic activity sector of Embrapii partner companies in the pilot phase.

\begin{tabular}{|c|c|}
\hline Sector of economic activity & No. of companies \\
\hline Cosmetics & 6 \\
\hline Oil and gas & 5 \\
\hline Chemical and petrochemical & 3 \\
\hline Drugs and medicine & 3 \\
\hline Medical and dentistry equipment & 3 \\
\hline Computer programs & 3 \\
\hline Experimental R\&D - natural sciences and physics & 3 \\
\hline Metallurgy & 3 \\
\hline Food processing & 2 \\
\hline Automobiles & 2 \\
\hline Auto parts & 2 \\
\hline Textiles & 1 \\
\hline Wood artifacts & 1 \\
\hline Intermediates for plasticizers, resins, and fibers & 1 \\
\hline Elastomers & 1 \\
\hline Pesticides & 1 \\
\hline Plastic artifacts & 1 \\
\hline Cement & 1 \\
\hline Appliances & 1 \\
\hline Agricultural irrigation & 1 \\
\hline Aircraft & 1 \\
\hline Furniture & 1 \\
\hline Minerals & 1 \\
\hline Informatics consulting & 1 \\
\hline Office and administrative services & 1 \\
\hline
\end{tabular}

Note. Source: the authors. 
Table 2. Data collection instruments and methods, type of respondent, sample and rate of response.

\begin{tabular}{|c|c|c|c|c|c|}
\hline $\begin{array}{l}\text { Data collection } \\
\text { instrument }\end{array}$ & $\begin{array}{l}\text { Data collection } \\
\text { method }\end{array}$ & Type of respondent & $\begin{array}{l}\text { No. of projects } \\
\text { (sample) }\end{array}$ & No. of responses & Rate of responses \\
\hline I1 & Online survey & $\begin{array}{l}\text { Project coordinators } \\
\text { in the research } \\
\text { organizations }\end{array}$ & $63^{(\mathrm{a})}$ & 62 & $98 \%$ \\
\hline $\mathrm{I} 2$ & Online survey & $\begin{array}{l}\text { Project managers in the } \\
\text { partner companies }\end{array}$ & $66^{(\mathrm{b})}$ & 44 & $67 \%$ \\
\hline $\mathrm{I} 3$ & $\begin{array}{l}\text { Face-to-face } \\
\text { semi-structured } \\
\text { questionnaires }\end{array}$ & $\begin{array}{l}\text { Experts in knowledge } \\
\text { fields of projects }\end{array}$ & 25 & 25 & $100 \%$ \\
\hline $\mathrm{I} 4$ & $\begin{array}{l}\text { Open interviews with } \\
\text { RO's CEOs }\end{array}$ & $\begin{array}{l}\text { Board of directors of } \\
\text { research organizations }\end{array}$ & - & $\begin{array}{l}3 \text { (one from each } \\
\text { research organization) }\end{array}$ & $100 \%$ \\
\hline
\end{tabular}

Note. ${ }^{(a)}$ This number refers to all the projects successfully executed in the pilot phase by the three research organizations (ROs) in cooperation with companies; ${ }^{(b)}$ One of the 63 projects involved four firms instead of just one and that is why there are 66 project managers in firms. Source: own elaboration.

The evaluators' team conducted the interviews with a group of people in ROs in charge of Embrapii's model implementation. Each interview lasted from two to three hours, and they were transcribed and coded to identify how the three ROs organized themselves to attend Embrapii's requirements regarding human resources, organizational units, management practices, governance, outputs, and outcomes. This was important to understand the context of project development in those accredited units and refine indicators employed in I1, I2, and I3.

Data from surveys and questionnaires were analyzed using descriptive and multivariate statistics, namely multiple correspondence followed by hierarchical cluster analysis, aiming to identify projects that were similar on input variables profile, characterizing clusters that might be compared on their output variables - this approach help to address key features that play an important role on estimated impacts.

Besides, I1 and I2 were compared to each other and to expert's views in order to identify if and to which extent perceptions from the different actors (RO's project coordinators, companies, and experts) converge. Two indicators were used to measure possible misalignments between answers from project executors in ROs and project managers in companies: (a) indicator of the discrepancy of figures, and (b) indicator of the opposition of figures - this one used to measure if answers had opposite directions.

\section{FINDINGS AND DISCUSSION}

Findings are presented in three blocks. The first block focuses on orientation issues, including project prospection and motivation and alignment between partners, as well as their social capital measured through previous cooperation experience. The second block concerns transaction issues from negotiation and contract to project management and execution. The third block is dedicated to the effectiveness of the arrangements. It comprehends the projects' outputs and outcomes with an emphasis on innovation generation and innovation capacity building.

In this way, blocks were organized following the two main categories of ROs-industry barriers, and in a complementary way, the final category addressing what was generated by the linkages.

\section{Project prospection}

How do ROs prospect with companies within Embrapii framework? As mentioned before, Embrapii's model presupposes that accredited ROs should actively look for companies interested in developing joint projects.

Figure 1 indicates that Embrapii's model was crucial to the establishment of the desired partnerships. From ROs perspective, the most common type of arrangement between $\mathrm{RO}$ and firms was new cooperation initiatives enabled by Embrapii's pilot phase; from the firm's perspective, the most frequent answer pointed to pre-existing cooperation initiatives catalyzed and reinforced by Embrapii's pilot phase.

One possible reason for the different perspectives concerning the evaluation of the same projects is that companies answered the survey based on their relationship with the RO. In contrast, ROs answered based on the relationship of their particularly accredited laboratories with the firms. This means that an essential share of the firms had previous experience with cooperation with ROs, which is considered in the literature as an incentive for further collaboration. 
In any case, the derived assumption is that Embrapii had an essential role in this process. The companies' answers about their interests in cooperation strengthen this conclusion since they declared that the willingness to cooperate was due to financial resources offered by Embrapii in the first place. They were secondly related to human, material, and infrastructure resources offered by ROs, following the literature that investigates the reasons for this kind of cooperation (Dietz \& Bozeman, 2005; Schaeffer et al., 2015).

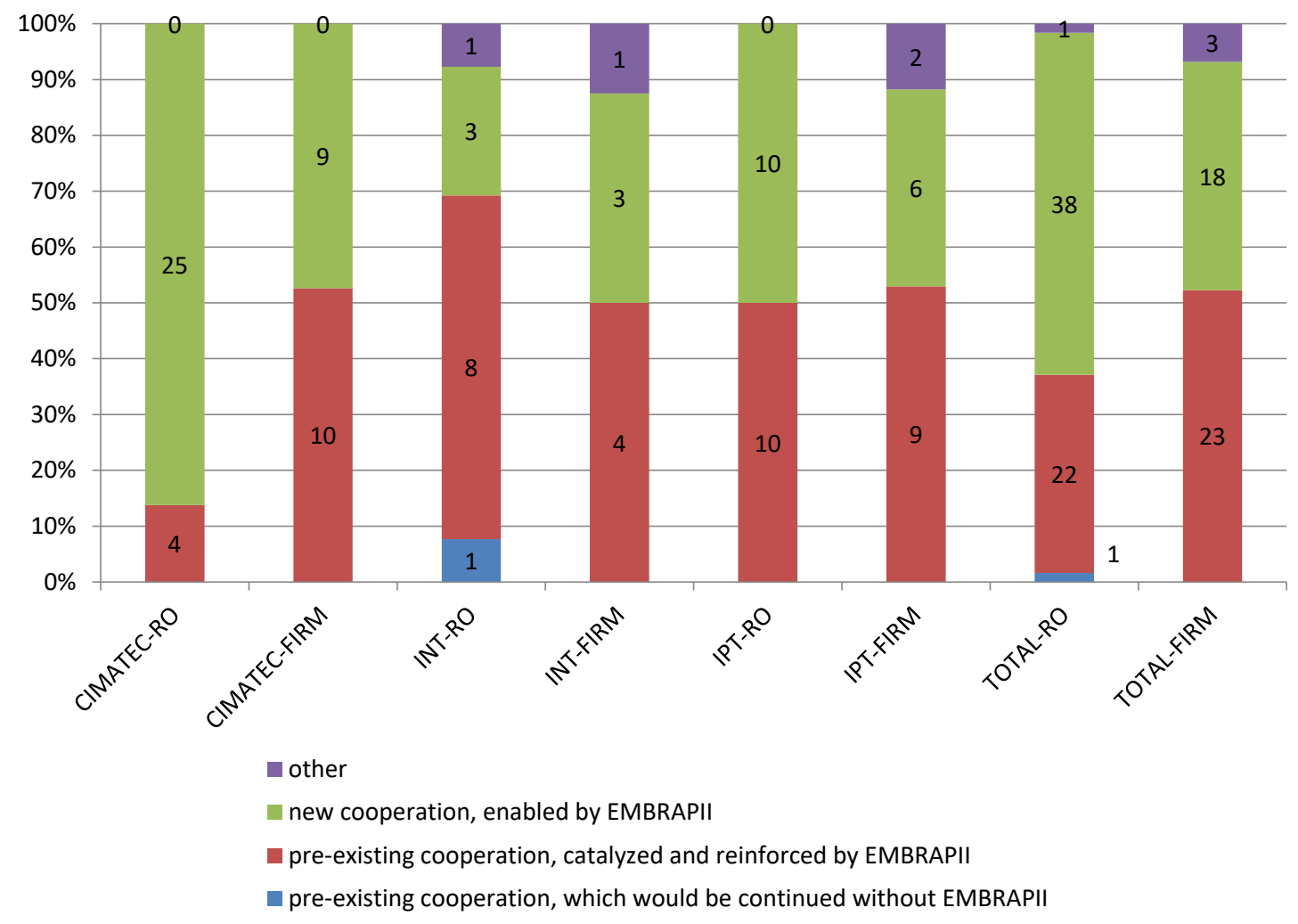

Figure 1. Type of arrangements established between research organizations and firms in projects and the role of Embrapii's pilot phase in this configuration (number of observations).

Source: data collection instruments I1 and I2. CIMATEC-RO: Perspective from project coordinator at RO-Cimatec. CIMATECFFIRM: Perspective from project manager at the firm level. INT-RO: Perspective from project coordinator at RO-INT. INT-FIRM: Perspective from project manager at the firm level. IPT-RO: Perspective from project coordinator at RO-IPT. IPT-FIRM: Perspective from project manager at the firm level.

When inquired about the motivation of cooperation, ROs highlight the firm's demands and secondly the combination of the firm's demands and their own interest (Figure 2). Conversely, firms highlight the combination of their demands and ROs supply and, in addition, their own demands. Once again, there are different views about the same phenomenon, although the firm's demands positively play a central role, by themselves or in combination with ROs competencies. This is the first set of evidence of how the model contributed to, at least partly, overcoming the linear model approach to innovation policies in developing countries (Dutrénit \& Arza, 2010) while trying to more effectively consider the firm's demands as a starting point to build a common perception of future challenges and opportunities (Kroll, 2016). Concomitantly, the answers indicate that being an accredited lab positively influenced the alignment of interests between parties, reducing transaction-related barriers.

As expected, Figures 1 and 2 also show a different perception amongst the three ROs. Despite being influenced by Embrapii's model, these organizations have particularly and historically defined routines and cultures that influence how they react to similar incentives. In the case of IPT, maybe because of its long-term experience to interact with companies, prevails the combination between supply and demand sides. In any case, it is worth noticing the importance of the demand side in defining subjects of research. 


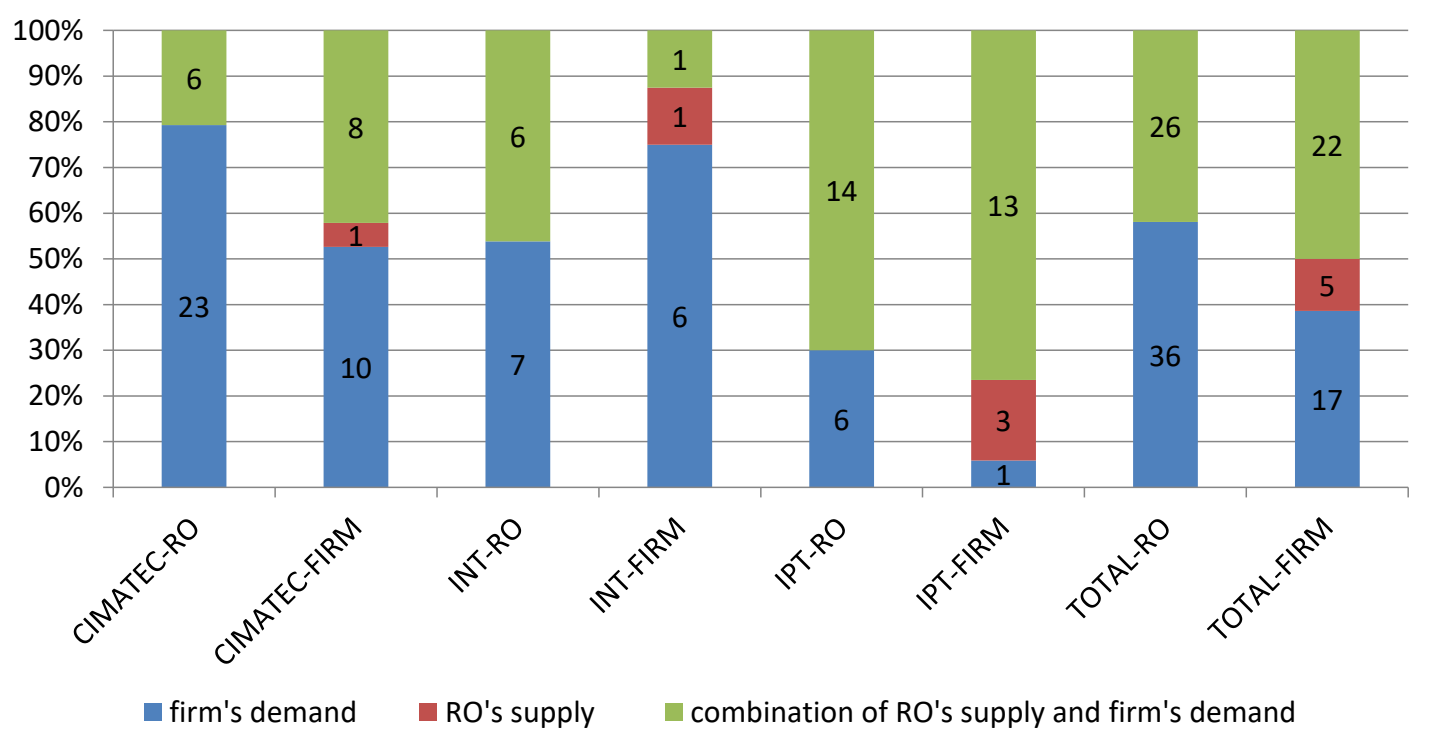

Figure 2. Main motivation to research organization (ROs) and firms to cooperate (number of observations). Source: data collection instruments I1 and I2. CIMATEC-RO: perspective from project coordinator at RO-Cimatec. CIMATEC-FIRM: perspective from project manager at the firm level. INT-RO: perspective from project coordinator at RO-INT. INT-FIRM: perspective from project manager at the firm level. IPT-RO: perspective from project coordinator at RO-IPT. IPT-FIRM: perspective from project manager at the firm level.

\section{Negotiation, contract, and project management}

The time spent for negotiation between ROs and companies was less than five months for $73 \%$ of the sample, which is a good average considering Brazilian standards for ROs (and mainly for public ROs, typically above six months). It also reveals more agility in delivering contracts in comparison with projects supported by public research agencies. For the $63 \%$ of ROs' project coordinators (I1), this time-reduction was due to Embrapii's model; for the $29 \%$ of ROs' project coordinators, it was partially due to Embrapii's model.

For the $82 \%$ of ROs' project coordinators, Embrapii's model has helped their organizations to create organizational structures and processes that increased their ability to identify opportunities and partners and to better manage partnerships with companies. This finding is following what Azevedo et al. (2016) reported, based on interviews with Embrapii managers to analyze the development of new capabilities to prospect partnerships, negotiate, and carry on complex contracts. A concrete example can be found in Azevedo and Tukoff-Guimarães (2015) that describes a new method of assessing the economic potential of technological innovation projects, developed and applied by IPT in the negotiations of commercial exploitation of technologies.
When asked about the specific factors of the Embrapii's model that facilitated prospection, negotiation, and contract of projects from the RO's perspective, respondents emphasized: (a) long-term flow of financial resources committed to their use; (b) financial counterpart in the same proportion by the other partners $(1 / 3$ the RO, 1/3 partner firm, 1/3 Embrapii); (c) flexibility for using budget; (d) projects with firms in the intermediary phase of innovation, among other less relevant factors. From the firm's perspective, the same factors were pointed out, although in a somewhat different order of importance. For both sides, intellectual property issues made prospection, negotiation, and contract processes more difficult to be executed.

The previous analysis of how the prospection and negotiation processes occur suggests that certain characteristics of Embrapii's model contributed to overcoming transaction-related barriers, except for intellectual property negotiations.

Regarding project management, a first point to be investigated is to what extent Embrapii's model encouraged the involvement of the companies' human resources in project development, including project planning, execution, and termination (with validation of results). It is worth noticing that such participation was not mandatory as a condition for the development of the project, although it was desirable to improve the alignment 
between the parties during the project execution and the potential use of its results.

In this regard, firms reported that $70 \%$ of the sample projects counted on some sort of involvement. For this group, the average was 0.7 people involved in the project's execution with partial dedication and about 0.5 people with exclusive dedication. The perception of ROs for the same issue is below the perception of companies: about $45 \%$ of the project coordinators at ROs reported as having constant personnel from industry taking part in project execution. A possible explanation is a different perception of what 'participation' means for both parties. All in all, companies considered that they had been involved in the vast majority of projects.

Still, positive results were found for project management processes. For $82 \%$ of ROs' project coordinators, projects employed guidelines, or project/ portfolio management tools, such as PMBoK. At Cimatec, it happened to all projects; at IPT to $77 \%$ of projects; and at INT to $60 \%$ of projects. Although previous engagement in best practices for $\mathrm{R} \& \mathrm{D}$ project management, the three organizations invested and generalized the adoption of such practices as a consequence of Embrapii's model. About $85 \%$ of ROs' project coordinators reported that they had changed their usual guidelines to manage and monitor R\&D and innovation projects in partnership with companies because of Embrapii's model, meaning that the model pushed ROs toward the professionalization of $R \& D$ project management.

For more than $81 \%$ of companies, projects had performed above or within initial expectations. The influence of Embrapii's model in this success rate was rated high to very high. The evidence that 48 out of 62 projects were considered by companies to be continued as new projects, or technical services, using the company's resource - with or without Embrapii's support -, reinforces the positive view reported by companies.

Once again, it is possible to believe that certain characteristics of Embrapii's model contributed to the construction and maintenance of an adequate relationship between ROs and firms. Additionally, it also changed the way ROs engage in R\&D collaborations. Following Sá and Litwin (2011) and Cunningham and Gök (2012), the stability of arrangements and resources, along with a long-term perspective of cooperation, positively influence the partnership.

The analysis suggests that participation in Embrapii's pilot phase changed the way $R O$ s engage in $R \& D$ collaborations with companies concerning their processes. This means that guidelines of more flexibility and higher levels of maturity in project management encouraged by
Embrapii were absorbed by ROs, facilitating the overcome of well-known transaction barriers among partners in collaboration initiatives. These findings were confirmed by ROs' directors interviewed in I4 as well as by project coordinators in instrument I1.

\section{Technological results, innovation, and capacity building}

Beyond generating changes in $\mathrm{ROs}$ related to orientation and transaction with firms, it was expected from Embrapii's pilot phase technological outputs oriented to innovation. As a result, we understand all the developments accomplished by the project when it has reached its final stage. These include products, materials, processes, equipment, software, and methodologies. Indeed, measuring this accomplishment helps to understand if the changes mentioned above related to orientation and transaction with firms reflected in achieving policy goals.

Figure 3 highlights that from the ROs' perspective, $89 \%$ of the projects generated some kind of technological result; from the firm's perspective, $66 \%$ of the projects did it. This reveals a more optimistic view of the project executors about the project outputs compared to the firm's understanding of whether the projects were achieved with the potential application or not. From the expert's perspective (I3), all of the 25 projects of the sample generated technological results. In just some few exceptions - a maximum of $10 \%$ of the cases -, results were not attributed to Embrapii to some degree.

Regarding the degree of novelty of technological results, ROs and companies had slightly different perceptions: for ROs, $17 \%, 48 \%$, and $35 \%$ were considered as new to the company level, country level, and world level, correspondingly. From the company's perspective, these figures were $18 \%, 32 \%$, and $50 \%$, respectively. As can be seen, companies had a more optimistic view of the originality of technological results.

Despite the pre-competitive nature of projects suggested in Embrapii's guidelines, it was meaningful to investigate the generation of innovation within the projects, since fostering innovation throughout research-industry cooperation is the long-term purpose of this policy. Eight innovations resulted from projects as reported by firms. Innovation was considered the implementation - either by introduction or by adoption - of new or significantly improved products and processes. Seven out of eight of them came from Cimatec's projects and one from INT. There were also 33 cases where innovation did not happen but was strongly expected. 


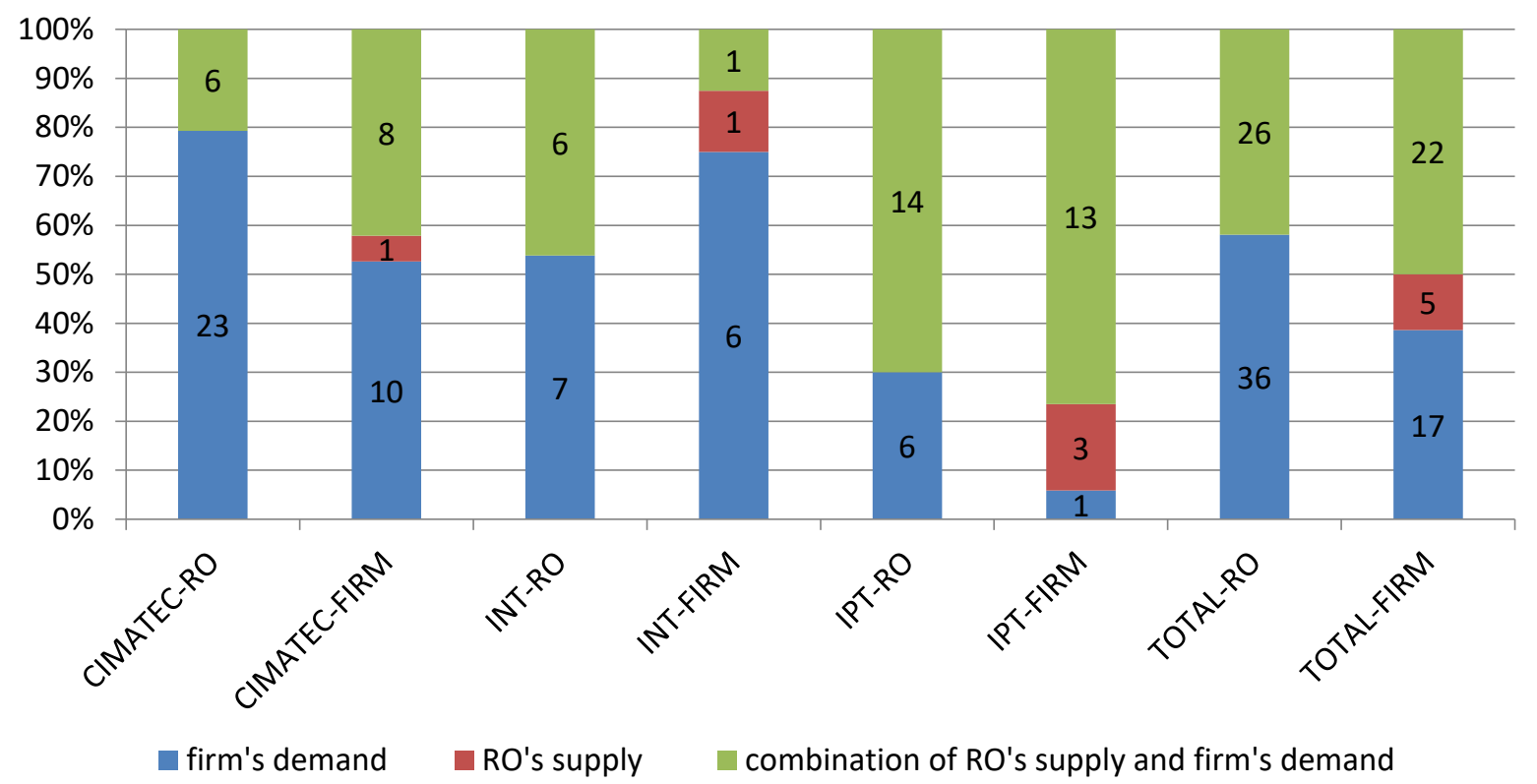

Figure 3. Occurrence of technological results with a potential future application (number of observations).

Source: data collection instruments I1 and I2. CIMATEC-RO: Perspective from project coordinator at RO-Cimatec. CIMATEC-FFIRM: Perspective from project manager at the firm level. INT-RO: Perspective from project coordinator at RO-INT. INT-FIRM: Perspective from project manager at the firm level. IPT-RO: Perspective from project coordinator at RO-IPT. IPT-FIRM: Perspective from project manager at the firm level.

As anticipated, there were still a few technological results that were introduced or adopted by companies. This occurred because there is an average temporal gap between obtaining a technological result and its implementation since complementary assets are required to support the successful introduction and commercialization of technological innovation (as proposed by Teece, 1986). This explains why firms considered concurrent factors beyond Embrapii as influential to the generation of innovations.

When inquired about the cases in which innovations are expected for the future, experts (I3) pointed out the essential role of firms in providing additional investments in R\&D and other complementary activities to support the introduction or implementation of new products and processes.

As for the observed impacts of innovation in the partner firms, the expected results include: the added value of existing products/services; higher quality of existing products/services; cost reduction; keep or expand the market share; opening new markets; expanding productive capacity; expansion of portfolio of products/services; increasing sales; reduction of environmental impacts.

In terms of generating new scientific and technological capabilities, the results are quite positive. Only in a few cases organizations - either firms or ROs - did not recognize the contribution of the projects in this respect. Most cases involve new competencies in managing cooperation, but also for creating new lines of research or at least the consolidation of existing ones.

Nearly $2 / 3$ of the projects reported generation of intellectual property rights from the perspective of ROs, while in the case of firms, the figure accounted for $50 \%$. Embrapii was considered highly influential in this process. Technological transfer agreements were reported in the case of several projects, also attributed to Embrapii's model.

The generation of technological results and competences brings evidence of additionality of outputs. The aggregated analysis suggested that Embrapii's model is working as predicted in this matter. Nevertheless, the medium- and long-term consequences of Embrapii implementation are still to be measured.

\section{Convergences and divergences between partners' perceptions}

As shown in the previous items, there are distinctive perceptions among ROs, firms, and experts about figures of some variables. Two indicators were created to measure misalignments between answers from project executors in ROs and project managers in companies: (a) indicator of the discrepancy of figures; and (b) indicator of the opposition of 
figures - this one used to measure if answers had opposite directions.

Discrepancy and opposition between ROs and firms occurred with more emphasis on project scope (if ideas investigated in the project were already being explored beforehand by the organizations), intellectual property, and allocation of personnel and material resources from companies in project development.

The degree of divergence of those indicators calls for more robust governance over projects, particularly on establishing mechanisms to validate data generated by projects. In other words, although there is positive evidence in reducing orientation and transaction barriers, the governance of projects still has to evolve.

\section{Multivariate analysis}

Despite the small size of the sample and the presence of only three ROs in the pilot phase cooperating with 44 companies, the assessment tried to find significant statistical regularities within the collected dataset, mostly between processes employed in ROs and outputs achieved by their projects. Multiple correspondence and cluster analyses were carried out mainly based on selected variables of survey I1 .

Three clusters were identified, with minor distinctions among them. The cluster analysis dendrogram can be found in Appendix II (Figure A1). Cluster 1 was dominated by Cimatec projects (22 from this $\mathrm{RO}$ and just one from IPT); Cluster 2 had a more balanced constitution -12 projects from INT, ten from IPT and eight from Cimatec; finally, Cluster 3 had eight projects from IPT and just one from INT and Cimatec.

Cluster 1 was a little more successful in the generation of technological results than the other two. Firm's demands played an essential role in projects from Cluster 1, while the balance between demand and supply motivated projects from Clusters 2 and 3. This finding shows relation (highlighted by Cluster 1) between the achievement of intended results from joint projects - i.e., technology generation and appropriation - and the demand-driven orientation.

In terms of management practices, Clusters 1 and 2 were more similar and could be considered as more professionalized than Cluster 3. Still, Cluster 3 seems less dependent on Embrapii, since this initiative contributed to projects already in development and with the allocation of external funding resources. Once again, better outputs come together with more mature processes for managing ROindustry cooperation, which is seen in Cluster 1, which is generally related to fewer transaction problems.

This analysis also reveals the very nature of ROs, since Cimatec is a private non-profit organization created by industry to promote research-industry linkages, while the other two were reasoned in a state-owned management model, being more recently reoriented to foster such linkages. For longer than INT, IPT has been driven to adopt a 'marketoriented' perspective since the end of the 1990s (Salles-Filho et al., 2000).

These analyses present evidence that the previous context of ROs is relevant to explaining differences in behavior and performance under Embrapii's model. Thus, beyond policy design, the institutional design of organizations involved in cooperation also matters in the promotion of better RO-firm's arrangements. The analysis also reinforces the common notion that organizational and behavioral transformations are expected to be tougher in organizations whose missions and culture are more driven by producers than by users of knowledge.

\section{CONCLUSIONS AND POLICY IMPLICATIONS}

Findings explored in this work revealed that Embrapii's model had a significant weight in promoting both behavioral and output additionality. That suggests the Embrapii's model has accomplished most of its initial intents. Beyond projects' output and outcomes in contributing to technology development and innovation processes in the partner companies, ROs improved their research and innovation management capabilities, such as those related to prospecting opportunities and partners, aligning perspectives, negotiating, contracting, and managing projects and fostering new partnerships. These changes were not homogenous amongst ROs, bringing evidence that organizational and cultural traits may have influenced the differences. All in all, there are shreds of evidence of behavioral additionality in ROs toward the professionalization of R\&D governance and management.

Concerning project outputs, findings showed that expected technological results such as new products, processes, and methodologies were achieved in the majority of projects. Although ROs reported higher accountings about these indicators, companies reported similar figures and revealed qualitative satisfaction with results. Intellectual property rights were generated in more than $50 \%$ of the projects. Moreover, projects contributed to the creation of new research areas or the consolidation of existing ones both in ROs and companies.

Experts hired to visit projects' sites confirmed that results were original, technically relevant, and pre-competitive in their design and execution. Some firms were already able to use the project's results in their internal processes or to commercialize the developed technologies, meaning that companies reported innovations based on the project's results. Impacts related to these innovations are observed primarily 
in terms of added value and quality improvement, but also in cost reduction and market share.

These findings bring evidence that Embrapii's policy design contributed for removing orientation barriers (as pointed out by Bruneel et al. (2010) since the model gives parties not only the freedom to negotiate and operate, but also requires, throughout accreditation, standards of organization and practices of operation that are conceived to reduce barriers of orientation and transaction. Besides, Embrapii's manager only allows projects to start spending the budget after a common definition of project's main subject, methodology, timeframe, expected results, and managerial practices.

Embrapii's model requires parties to interact from the beginning: from the prospection of companies interested in spending resources in $\mathrm{R} \& \mathrm{D}$ in a cooperative way until the completion of a project (companies are formally demanded by Embrapii to give their final appraisal for project completion). They also have to engage in project monitoring. The very basic premise of Embrapii of having accredited units supports this alignment since ROs must be prepared to collaborate, having in mind demands from their partners.

From the transaction barriers standpoint, Embrapii's model gives ROs a well-defined path to manage resources. According to an action plan (the basic long-term plan that guides all accredited Embrapii's unit), awarded funds can only be spent in projects where - and when - companies match funds with their own financial resources. Among other requirements that can be seen in the Embrapii's model, ROs are stimulated to develop managerial standards to deal with collaborative industrial $\mathrm{R} \& \mathrm{D}$ projects - such as PMBok or related training in $\mathrm{R} \& \mathrm{D}$ project management. This forces organizations to professionalize their internal processes and personnel capabilities, adopting R\&D management best practices. It also induces a reorganization of governance standards at ROs.

Embrapii's process of accreditation also contributes to this matter, since it contributes to the medium- to longterm maturation of management processes. It also helps to construct the required social capital of ROs that influence further collaborations.

Azevedo et al. (2016) suggest that "the standardization of Embrapii's operating model provided operational benefits to ROs such as process controls, contracts, and execution of projects that did not exist previously. ... As a result, the new institutional design resulted in the acquisition of the capabilities of 'public-private collaboration' and 'experimentation and learning."” (Azevedo et al., 2016, p. 35). The authors claim that these new organizational skills developed by ROs are more conducive to triggering innovation within firms.

Our work suggests similar findings, adding the company's and expert's perspectives and hinting the desired relation between the surpass of orientation and transactional barriers and the contribution of partnerships to technological development and innovation processes.

From a conceptual perspective, this article offers a twofold contribution. The first contribution is to the discussion of the obstacles and barriers for research-industry linkages integrating some previous studies (Bruneel et al., 2010; Filippetti \& Savona, 2017; Muscio \& Vallanti, 2014; Simachev, Kuzyk, \& Feygina, 2014). The second is related to the main challenges of policy design and implementation to overcome these barriers from a global perspective (Borrás \& Edquist, 2013; Cunningham \& Gök, 2012; Dutrénit \& Arza, 2010; Kroll, 2016; Radosevic, 2011; Veletanlić \& Sá, 2019) and from a Brazilian one (Albuquerque et al., 2015; Fernandes et al., 2010; Pinho \& Fernandes, 2015; Schaeffer et al., 2015).

From an empirical point of view, the study enabled a comprehensive assessment of Embrapii initial phase regarding processes and outputs. Finally, from a methodological point of view, the main contributions presented by this article relate to the proposition and validation of indicators (see Appendix I) that allow the measurement of input, output, and behavioral additionality in similar research-industry collaboration policies/models.

In terms of policy implications, there are also valuable lessons for companies and ROs, in particular those related to the influence of management practices on successful partnerships outputs. This means that though human, material, and infrastructure resources of ROs are attractive for companies looking for collaboration, they are not sufficient conditions for achieving shared project goals. Close interaction, agility, professionalism, governance practices, among other issues, seem to be crucial for both sides.

The main limitations of the study are as follows: (a) the impossibility of using control groups in the evaluation design, since the pilot phase was not organized by a competitive call from which awardees ROs could be compared with those not supported; (b) the time frame used in the evaluation. As discussed in specialized literature, there is an ordinary temporal gap between obtaining a technological result and its implementation as innovation and consolidating management routines. In this case, it can also be said that further progress in the implementation of Embrapii could provide more adequate time frames for evaluation; (c) the low number of $\mathrm{ROs}$ in the pilot phase - just three research organizations - limits the conclusions.

Finally, despite the evidence presented here about the benefits brought by Embrapii pilot phase, further investigation on this subject is still needed. It should integrate the growing efforts to evaluate science, technology, and innovation programs, and policies in multiple dimensions, as for the economic, social, and environmental dimensions. 


\section{REFERENCES}

Albuquerque, E., Suzigan, W., Kruss, G., \& Lee, K. (2015). Developing national systems of innovation: Universityindustry interactions in the global south. Cheltenham, UK: Edward Elgar Publishing.

Ahuja, G. (2000). Collaboration networks, structural holes, and innovation: A longitudinal study. Administrative Science Quarterly, 45(3), 425-455. https://doi.org/10.2307/2667105

Arocena, R., \& Sutz, J. (2003). Knowledge, innovation and learning: Systems and policies in the north and in the south. In J. E. Cassiolato, H. M. M. Lastres, M. L. Maciel (Eds.), Systems of innovation and development: Evidence from Brazil. Cheltenham, UK: Edward Elgar Publishing.

Arza, V. (2010). Channels, benefits and risks of public-private interactions for knowledge transfer: Conceptual framework inspired by Latin America. Science and Public Policy, 37(7), 473-484. https://doi.org/10.3152/030234210X511990

Azevedo, P. F., Saes, M. S., Schneider, P. S. B., Carvalho, T. B., Francischini, A. S. N., Santana, S. K. S., \& Morgulis, M. C. A. (2016). Learning from productive development agencies in Brazil, policies for technological innovation [Working Paper n. IDB-WP-765]. Inter-American Development Bank, Department of Research and Chief Economist. Sao Paulo, SP, Brazil. Retrieved from https://publications. iadb.org/en/learning-productive-development-agenciesbrazil-policies-technological-innovation

Azevedo, P. B. M. de, \& Tukoff-Guimarães, Y. B. (2015). IPT's quick \& dirty economic valuation method: An empirical test on three cases. Chinese Business Review, 14(1), 1-7. https://doi.org/17265/1537-1506/2015.01.001

Borrás, S., \& Edquist, C. (2013). The choice of innovation policy instruments. Technological Forecasting and Social Change, 80(8), 1513-1522. https://doi.org/10.1016/j.techfore.2013.03.002

Bruneel, J., D'Este, P., \& Salter, A. (2010). Investigating the factors that diminish the barriers to universityindustry collaboration. Research Policy, 39(7), 858-868. Retrieved from https://ideas.repec.org/a/eee/respol/ v39y2010i7p858-868.html

Caloghirou, Y., Tsakanikas, A., \& Vonortas, N. S. (2001). Universityindustry cooperation in the context of the european framework programmes. The Journal of Technology Transfer, 26(1-2), 153-161. Retrieved from https://econpapers. repec.org/RePEc:kap:jtecht:v:26:y:2001:i:1-2:p:153-61

Cheng, H., Zhang, Z., Huang, Q., \& Liao, Z. (2018). The effect of university-industry collaboration policy on universities' knowledge innovation and achievements transformation: Based on innovation chain. The Journal of Technology Transfer, 45, 522-543. https://doi.org/10.1007/s10961-018-9653-9

Cohen, W., Nelson, R., \& Walsh, J. (2002). Links and impacts: The influence of public research on industrial R\&D. Management Science, 48(1), 1-23. Retrieved from http://www.jstor.org/stable/822681.
Confraria, H., \& Vargas, F. (2019). Scientific systems in Latin America: Performance, networks, and collaborations with industry. The Journal of Technology Transfer, 44, 874915. https://doi.org/10.1007/s10961-017-9631-7

Cruz, C. H. B. (2019) Benchmarking university/ industry research collaboration in Brazil. In E. B. Reynolds, B. R. Schneider, E. Zylberberg (Eds.), Innovation in Brazil: Advancing development in the 21st century. London: Routledge.

Cullen, J. B., Johnson, J. L., \& Sakano, T. (2000). Success through commitment and trust: The soft side of strategic alliance management. Journal of World Business, 35(3), 223-240. Retrieved from https://ideas.repec.org/a/eee/worbus/ v35y2000i3p223-240.html

Cunningham, P., \& Gök, A. (2012). The impact and effectiveness of policies to support collaboration for R\&D and innovation [Nesta Working Paper No. 12/06]. Nesta. London, UK. Retrieved from https://www.nesta.org.uk/report/ the-impact-and-effectiveness-of-policies-to-supportcollaboration-for-rd-and-innovation/

Cunningham, J. A., \& Link, A. N. (2015). Fostering universityindustry R\&D collaborations in European Union countries. International Entrepreneurship and Management Journal, 11, 849-860. https://doi.org/10.1007/s11365-014-0317-4

Dietz, J., \& Bozeman, B. (2005). Academic careers, patents, and productivity: Industry experience as scientific and technical human capital. Research Policy, 34(3), 349-367. https://doi.org/10.1016/j.respol.2005.01.008

Dutrénit, G., \& Arza, V. (2010). Channels and benefits of interactions between public research organisations and industry: Comparing four latin american countries. Science and Public Policy, 37(7), 541-553. Retrieved from https:// ideas.repec.org/a/oup/scippl/v37y2010i7p541-553.html

Empresa Brasileira de Pesquisa e Inovação Industrial. (2018). Quem somos. Retrieved from https://embrapii.org.br/institucional/quem-somos/

Empresa Brasileira de Pesquisa e Inovação Industrial. (2019). Relatório plurianual 2014-2019. Retrieved from https://embrapii.org.br/wp-content/images/2020/01/ embrapii 2014-2019 2P.pdf

Etzkowitz, H. (1998). The norms of entrepreneurial science: Cognitive effects of the new universityindustry linkages. Research Policy, 27(8), 823-833. https://doi.org/10.1016/S0048-7333(98)00093-6

Etzkowitz, H., \& Leydesdorff, L. (2000). The dynamics of innovation: From national systems and "mode 2" to a triple helix of university-industry-government relations. Research Policy, 29(2), 109-123. https://doi.org/10.1016/S0048-7333(99)00055-4

Etzkowitz, H., \& Zhou, C. (2008). Introduction to special issue Building the entrepreneurial university: A global perspective. Science and Public Policy, 35(9), 627-635. https://doi.org/10.3152/030234208X363178 
Fernandes, A. C, Souza, B. C. de., Silva, A. S. da., Zuzingan, W, Chaves, C. V., \& Alburquerque, E. (2010). Academyindustry links in Brazil: Evidence about channels and benefits for firms and researchers. Science and Public Policy, 37(7) 485-498. Retrieved from https://ideas.repec.org/a/ oup/scippl/v37y2010i7p485-498.html

Ferreira, M. L. A., \& Ramos, R. R. (2015). Making universityindustry technological partnerships work: A case study of the brazilian oil innovation system. Journal of Technology Management and Innovation, 10(1), 173-187. https://dx.doi.org/10.4067/S0718-27242015000100013

Filippetti, A., \& Savona, M. (2017). University-industry linkages and academic engagements: Individual behaviors and firms' barrier. Introduction to the special section. The Journal of Technology Transfer, 42(4), 719-729. https://doi.org/10.1007/s10961-017-9576-x

Fischer, B. B., Schaeffer, P. R., Vonortas, N. S. \& Queiroz, S. (2017). Quality comes first: University-industry collaboration as a source of academic entrepreneurship in a developing country. The Journal of Technology Transfer, 43(2), 263284. https://doi.org/10.1007/s10961-017-9568-x

Freitas, I. A. B., Marques, R. A., \& Silva, E. M. de P. (2013). University-industry collaboration and innovation in emergent and mature industries in new industrialized countries. Research Policy, 42(2), 443-453. https://doi.org/10.1016/j.respol.2012.06.006

Garcia, R., Araujo, V., Mascarini, S., Santos, E. G. dos., \& Costa, A. R. (2014). University-industry linkages and the influence of the characteristics of academic research groups. Revista de Economia Contemporânea, 18(1), 125146. https://doi.org/10.1590/141598481816

Goulart, L. N. (2012). Políticas de ciência, tecnologia e inovação no Brasil e sua relação com a sustentabilidade do crescimento econômico. Revista do TCU, (124), 60-71. Retrieved from https://revista.tcu.gov.br/ojs/index.php/RTCU/article/ view/131

Guimón, J. (2013). Promoting university-industry collaboration in developing countries. The innovation policy platform. Washington, DC: The World Bank. Retrieved from https://www.ncba.in/assets/Reports/PromotingUniversityIndustryCollaborationInDevelopingCountries.pdf

Hagedoorn, J., Link, A. N., \& Vonortas, N. S. (2000). Research partnerships. Research Policy, 29(4-5), 567-586. https://doi.org/10.1016/S0048-7333(99)00090-6

Instituto Brasileiro de Geografia e Estatística. (2020). Pesquisa de Inovação - 2017. Retrieved from https://sidra.ibge.gov.br/pesquisa/pintec/tabelas

Kaufmann, A., \& Tödtling, F. (2001). Science-industry interaction in the process of innovation: The importance of boundarycrossing between systems. Research Policy, 30(5), 791-804. https://doi.org/10.1016/S0048-7333(00)00118-9

Kroll, H. (2016). Supporting new strategic models of science-industry ROD collaboration: A review of global experiences. Karlsruhe: Fraunhofer Institute for Systems and Innovation Research.
Mazzoleni, R., \& Nelson, R. (2007). Public research institutions and economic catch-up. Research Policy, 36(10), 15121528. https://doi.org/10.1016/j.respol.2007.06.007

Muscio, A., \& Vallanti, G. (2014). Perceived obstacles to university-industry collaboration: Results from a qualitative survey of italian academic departments. Industry and Innovation, 21(5), 410-429. https://doi.org/10.1080/13662716.2014.969935

Negri, F. de., \& Cavalcante, L. R. (2014). Os dilemas e os desafios da produtividade no Brasil. In Produtividade no Brasil: Desempenho e determinantes (pp. 15-51). Brasília: Instituto de Pesquisa Econômica Aplicada - IPEA

Negri, F. de., \& Rauen, A. T. (2018). Innovation policies in Brazil during the 2000s: The need for new paths [IPEA Discussion Paper DP 0235]. Brasília, DF, Brazil. Retrieved from https://www.ipea.gov.br/portal/index.php?option=com content \&view=article\&id=34245\&Itemid $=433$

Organization for Economic Co-Operation and Development. (2019). Oslo manual: Guidelines for collecting, reporting and using data on innovation (4 ed). Paris: OECD. Retrieved from https://www.oecd.org/science/oslo-manual-20189789264304604-en.htm

Pacheco, C. A., Bonacelli, M. B. M., \& Foss, M. C. (2017). Políticas de estímulo à demanda por inovação e o Marco Legal de CT\&I. In D. R. Coutinho, M. C. Foss, P. S. B. Mouallem (Orgs.), Inovação no Brasil: Avanços e desafios jurídicos e institucionais (pp. 213-40). São Paulo: Blucher.

Pacheco, C. A. (2019) Institutional dimensions of innovation policy in Brazil. In E. Reynolds, B. Schneider, E. Zylberberg (Eds.), Innovation in Brazil: Advancing Development in the 21st Century (Chap. 7). London: Routledge. https://doi.org/10.4324/9780429053092

Pinho, M., \& Fernandes, A. C. (2015). Relevance of universityindustry links for forms from developing countries: Exploring different surveys. In E. Alburquerque, W. Suzigan, G. Kruss, K. Lee (Eds.), Developing national systems of innovation: University-industry interactions in the global south (pp. 145-163). Cheltenham, UK: Edward Elgar Publishing.

Radosevic, S. (2011). Science-industry links in central and eastern europe and the commonwealth of independent states: Conventional policy wisdom facing reality. Science Public Policy, 38(5), 365-378. https://doi.org/10.3152/030234211X12924093660435

Rapini, M., Albuquerque, E., Chave, C., Silva, L., Souza, S., Righi, H., \& Cruz, W. (2009). University-industry interactions in an immature system of innovation: Evidence from Minas Gerais, Brazil. Science and Public Policy, 36(5), 373-386. https://doi.org/10.3152/030234209X442016

Rauen, C. V., \& Turchi, L. (2017). Apoio à inovação por institutos públicos de pesquisa: limites e possibilidades legais da interação ICT-empresa. In L. M. Turchi, J. M. Morais (Orgs.), Políticas de apoio à inovaçâo tecnológica no Brasil: Avanços recentes e propostas de açôes. Brasília: Instituto de Pesquisa Econômica Aplicada - IPEA. 
Rocha, M.., Lima, G., Lameira, V., \& Quelhas, O. (2012). Innovation as a critical success factor: An exploratory study about the partnership among university with pharmaceutical industry in Brazil. Journal of Technology Management and Innovation, 7(3), 148-160. https://doi.org/10.4067/S0718-27242012000300013

Sá, C. M., \& Litwin, J. (2011). University-industry research collaborations in Canada: The role of federal policy instruments. Science and Public Policy, 38(6), 425-435. Retrieved from https://ideas.repec.org/a/oup/scippl/ v38y2011i6p425-435.html

Salles-Filho, S., Albuquerque, R., Szmrecsányi, T., Bonacelli, M. B., Paulino, S., Bruno, M., Mello, D., Corazza, R., Carvalho, S., Corder, S., \& Ferreira, C. (2000). Ciência, tecnologia e inovação: A reorganização da pesquisa pública no Brasil. Campinas: Editora Komedi.

Salles-Filho, S. (2002). Política de ciência e tecnologia no I PND (1972/74) e no I PBDCT (1973/74). Revista Brasileira de Inovação, 1(2), 397-419. https://doi.org/10.20396/rbi.v1i2.8648865

Salles-Filho, S. (2003a). Política de ciência e tecnologia no II PBDCT (1976). Revista Brasileira de Inovação, 2(1), 179211. https://doi.org/10.20396/rbi.v2i1.8648872

Salles-Filho, S. (2003b). Política de ciência e tecnologia no III PBDCT (1980/1985). Revista Brasileira de Inovação, 2(2), 407-432. https://doi.org/10.20396/rbi.v2i2.8648878

Salles-Filho, Sergio L. M., Avila, A. F, Alonso, O. S., \& Colugnati, F. A. B. (2010). Multidimensional assessment of technology and innovation programs: The impact evaluation of INCAGRO-Peru. Research Evaluation, 19(5), 361-372. https://doi.org/10.3152/095820210X12904313498360

Salles-Filho, S., Bonacelli, M. B., Carneiro, A. M., Castro, P. F. D., \& Santos, F. O. (2011). Evaluation of ST\&I programs: A methodological approach to the Brazilian small business program and some comparisons with the SBIR program. Research Evaluation, 20(2), 159-171. https://doi.org/10.3152/095820211X12941371876184

Schaeffer, P. R., Ruffoni, J., \& Puffal, D. (2015). Razóes, benefícios e dificuldades da interação universidadeempresa. Revista Brasileira de Inovação, 14(1), 105-134. https://doi.org/10.20396/rbi.v14i1.8649091

Silva Neto, F. C. C., Santos, U. P., Oliveira, V. P., Castro, P. G., Franco, L. T. M, \& Negri, F. (2013). Patterns of interaction between national and multinational corporations and Brazilian universities/public research institutes. Science and Public Policy, 40(3), 281-292. https://doi.org/10.1093/scipol/scs105

Simachev, Y., Kuzyk, M., \& Feygina, V. (2014). Cooperation between Russian research organizations and industrial companies: Factors and problems [MPRA Paper 55703]. Munich Personal RePEc Archive. Retrieved from https://mpra.ub.uni-muenchen.de/57503/1/MPRA paper 57503.pdf
Steinmo, M., \& Rasmussen, E. (2018). The interplay of cognitive and relational social capital dimensions in university-industry collaboration: Overcoming the experience barrier. Research Policy, 47(10) 1964-1974. https://doi.org/10.1016/j.respol.2018.07.004

Suzigan, W., Albuquerque, E., García, R., \& Rapini, M. (2009). University and industry linkages in Brazil: Some preliminary descriptive and descriptive results. Seoul Journal of Economics, 22(4), 591-611. Retrieved from http://hdl.handle.net/10371/67717

Tartari, V., \& Breschi, S. (2012). Set them free: Scientists' evaluations of the benefits and costs of university-industry research collaboration. Industrial and Corporate Change, 21(5), 1117-1147. https://doi.org/10.1093/icc/dts004

Teece, D. J. (1986) Profiting from technological innovation: Implications for integration, collaboration, licensing and public policy. Research Policy, 15(6), 285-305. https://doi.org/10.1016/0048-7333(86)90027-2

Teng, H. (2010). University-industry technology transfer: Framework and constraints. Journal of Sustainable Development, 3(2), 296-300. https://doi.org/10.5539/jsd.v3n2p296

Terra, B., Batista, L. A., Campos, S. R. C., \& Almeida, M. (2013). Interaction among universities, government and spin-off companies in a Brazilian context to generate sports innovation. Journal of Technology Management and Innovation, 8(2), 93-106. https://doi.org/10.4067/S0718-27242013000200008

Toledo, G., Castro, F. P., \& Gilaberte, T. P. (2017). A EMBRAPII como perspectiva à inovação. Cadernos de Prospecção, 10(2), 164-176. https://doi.org/10.9771/cp.v10i2.17704

Vaaland, T. I., \& Ishengoma, E. (2016) University-industry linkages in developing countries: Perceived effect on innovation. Education + Training, 58(9), 1014-1040. https://doi.org/10.1108/ET-07-2015-0067

Veletanlić, E., \& Sá, C. (2019) Government programs for universityindustry partnerships: Logics, design, and implications for academic science. Research Evaluation, 28(2), 109-122. https://doi.org/10.1093/reseval/rvy034

Wilson, T. (2012). A review of business-university collaboration. London: Higher Education Funding Council for England.

Zhou, P., Tijssen, R., \& Leydesdorff, L. (2016) Universityindustry collaboration in China and the USA: A bibliometric comparison. PLoS ONE, 11(11), e0165277. https://doi.org/10.1371/journal.pone.0165277

Zuniga, P., Negri, F., Dutz, M. A., Pilat, D., \& Rauen, A. (2016). Conditions for innovation in Brazil: A review of key issues and policy challenges [IPEA Discussion Paper DP 0218]. Instituto de Pesquisa Econômica Aplicada, Brasília, DF, Brazil. Retrieved from https://www.ipea.gov.br/portal/index. php?option=com_content $\&$ view $=$ article $\&$ id $=28969: \mathrm{dp}$ 0218-conditions-for-innovation-in-brazil-a-review-of-key$\underline{\text { issues-and-policy-challenges } \& \text { catid }=395: 2016 \& \text { directo }}$ $\mathrm{ry}=1$ 


\section{Authorship}

\section{Sergio Salles-Filho}

Universidade Estadual de Campinas, Instituto de Geociências, Departamento de Política Científica e Tecnológica

Rua Carlos Gomes, no 250, Cidade Universitária, 13083-855, Campinas, SP, Brazil.

E-mail address: sallesfi@ige.unicamp.br

(1) https://orcid.org/0000-0002-8727-4500

\section{Adriana Bin}

Universidade Estadual de Campinas, Faculdade de Ciências Aplicadas

R. Pedro Zaccaria, no 1300, Jardim Santa Luiza, 13484-350, Limeira, SP, Brazil.

E-mail address: adriana.bin@fca.unicamp.br

(1) https://orcid.org/0000-0001-9774-2753

\section{Kleinsy Bonilla*}

Universidade Estadual de Campinas, Instituto de Geociências, Departamento de Política Científica e Tecnológica

Rua Carlos Gomes, no 250, Cidade Universitária, 13083-855, Campinas, SP, Brazil.

E-mail address: kleinsy@gmail.com

(1) https://orcid.org/0000-0002-5097-508X

\section{Fernando Antonio Basile Colugnati}

Universidade Federal de Juiz de Fora, Programa de Pós-Graduação em Saúde

Av. Eugênio do Nascimento, s/nº, Dom Bosco, 36038-330, Juiz de Fora, MG, Brazil.

E-mail address: fernando.colugnati@uff.edu.br

(1) http://orcid.org/0000-0002-8288-203X

* Corresponding Author

\section{Funding}

The authors state that there are no funders to report for this article.

\section{Copyrights}

RAC owns the copyright to this content.

\section{Conflict of Interests}

The authors have stated that there is no conflict of interest.

\section{Authors' Contributions}

$1^{\text {st }}$ author: conceptualization (lead); data curation (equal); project administration (lead); methodology (lead); resources (lead); validation (lead); writing - original draft (equal).

$2^{\text {nd }}$ author: conceptualization (equal); data curation (equal); supervision (lead); project administration (equal); writing original draft (lead); visualization (lead).

$3^{\text {rd }}$ author: investigation (supporting); visualization (supporting); writing original draft (equal); writing - review $\&$ editing (equal).

$4^{\text {th }}$ author: formal analysis (equal); investigation (supporting); data curation (equal); resources (equal).

\section{Plagiarism Check}

The RAC maintains the practice of submitting all documents approved for publication to the plagiarism check, using specific tools, e.g.: iThenticate.

\section{Peer Review Method}

This content was evaluated using the double-blind peer review process. The disclosure of the reviewers' information on the first page is made only after concluding the evaluation process, and with the voluntary consent of the respective reviewers.

\section{Data Availability}

The datasets generated and/or analyzed during the current study are available in the Harvard Dataverse platform. The authors also acknowledge that the data has never been used in any previously published study.

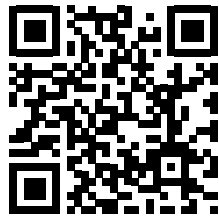

Sergio Salles-Filho; Adriana Bin; Kleinsy Bonilla; Fernando Antonio Basile Colugnati, 2021, "Replication Data for: "Effectiveness by Design: Overcoming Orientation and Transaction Related Barriers in ResearchIndustry Linkages"", Harvard Dataverse, V1. https://doi.org/10.7910/DVN/BRU7RI

RAC encourages data sharing but, in compliance with ethical principles, it does not demand the disclosure of any means of identifying research subjects, preserving the privacy of research subjects. The practice of open data is to enable the reproducibility of results, and to ensure the unrestricted transparency of the results of the published research, without requiring the identity of research subjects. 


\section{APPENDIX I - LIST OF INDICATORS EMPLOYED IN ALL INSTRUMENTS}

Table A1. Indicators employed in data collection instruments and the use of redundant causality factor.

\begin{tabular}{|c|c|c|c|c|}
\hline Indicator & I1 & I2 & I3 & $\begin{array}{l}\text { Redundant } \\
\text { causality factor }\end{array}$ \\
\hline Previous relations between ROs and firms & $\mathrm{X}$ & $\mathrm{x}$ & & $\mathrm{X}$ \\
\hline Willingness to cooperate & & $\mathrm{x}$ & & \\
\hline Motivation to project development & $\mathrm{X}$ & $\mathrm{x}$ & & \\
\hline Negotiation time & $\mathrm{X}$ & & & $\mathrm{X}$ \\
\hline $\begin{array}{l}\text { Agility in delivering contracts in comparison with projects } \\
\text { supported by public research agencies }\end{array}$ & $\mathrm{X}$ & & & \\
\hline $\begin{array}{l}\text { Creation of new management practices and organizational } \\
\text { structures related to prospection and negotiation of partnerships }\end{array}$ & $\mathrm{X}$ & & & $\mathrm{X}$ \\
\hline $\begin{array}{l}\text { Specific factors of the Embrapii's model that facilitated } \\
\text { prospection, negotiation, and contract of projects from the RO's } \\
\text { perspective }\end{array}$ & $\mathrm{X}$ & $\mathrm{x}$ & & \\
\hline $\begin{array}{l}\text { Involvement of companies' human resources in project } \\
\text { development }\end{array}$ & $\mathrm{X}$ & $\mathrm{x}$ & & \\
\hline Additional fundraising for Embrapii's projects & $\mathrm{X}$ & $\mathrm{x}$ & & \\
\hline \multicolumn{5}{|l|}{$\begin{array}{l}\text { Adoption of project management guidelines or project/portfolio } \\
\text { management tools }\end{array}$} \\
\hline $\begin{array}{l}\text { Creation of new management practices and organizational } \\
\text { structures related to management and monitoring partnerships }\end{array}$ & $\mathrm{X}$ & & & $\mathrm{X}$ \\
\hline Satisfaction with project progress and achievement of results & & $\mathrm{x}$ & & $\mathrm{X}$ \\
\hline $\begin{array}{l}\text { New partnerships between ROs and firms as a consequence of } \\
\text { Embrapii's projects }\end{array}$ & $\mathrm{X}$ & $\mathrm{x}$ & & \\
\hline \multicolumn{5}{|l|}{$\begin{array}{l}\text { Specific factors of the Embrapii's model that facilitated the } \\
\text { development of projects from the RO's perspective }\end{array}$} \\
\hline Generation of technological results & $\mathrm{X}$ & $\mathrm{x}$ & $\mathrm{x}$ & $\mathrm{X}$ \\
\hline Degree of novelty & $\mathrm{X}$ & $\mathrm{x}$ & $\mathrm{x}$ & \\
\hline Generation of innovation & $\mathrm{X}$ & $\mathrm{x}$ & $\mathrm{x}$ & $\mathrm{X}$ \\
\hline Impacts of innovation (potential and observed) & $\mathrm{X}$ & $\mathrm{x}$ & $\mathrm{x}$ & \\
\hline Generation of scientific and technological competences & $\mathrm{X}$ & $\mathrm{x}$ & $\mathrm{x}$ & \\
\hline Generation of intellectual property rights & $\mathrm{X}$ & $\mathrm{x}$ & $\mathrm{x}$ & $\mathrm{X}$ \\
\hline Generation of technology transfer agreements & $\mathrm{X}$ & $\mathrm{x}$ & $\mathrm{x}$ & $\mathrm{X}$ \\
\hline
\end{tabular}

Note. Source: the authors 


\section{APPENDIX II - CLUSTER ANALYSIS DENDROGRAM}

The multiple correspondence analysis and the hierarchical cluster analysis were based on the following indicators:

- Previous relations between ROs and firms

- Motivation to project development

- Creation of new management practices and organizational structures related to prospection and negotiation of partnerships

- Involvement of companies' human resources in project development

- Additional fundraising for Embrapii's projects

- Adoption of project management guidelines or project/portfolio management tools

- Generation of technological results

- Generation of scientific and technological competences

- Generation of intellectual property rights

- Generation of technology transfer agreements

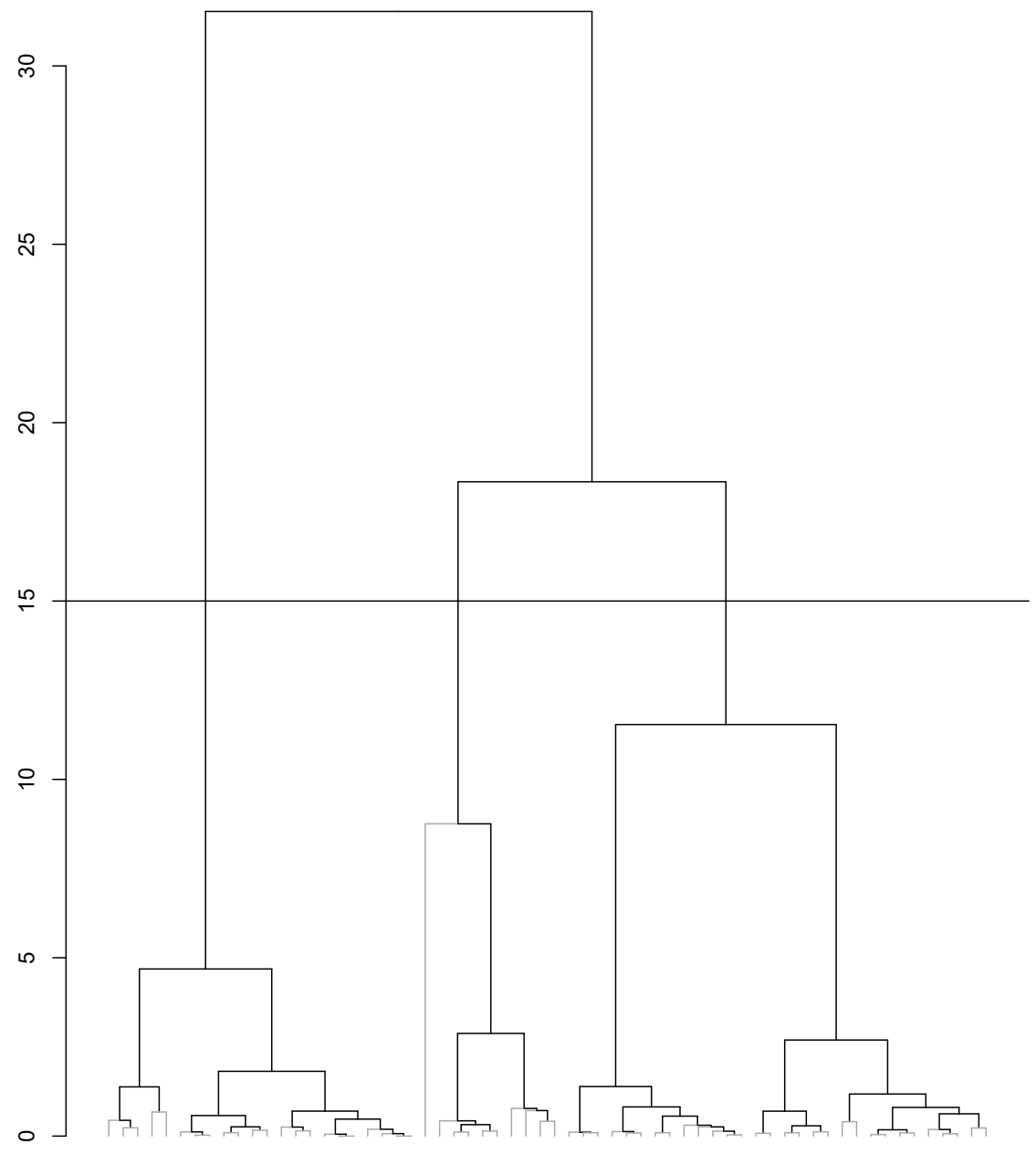

Figure A1. Dendrogram obtained from cluster analysis.

Source: the authors. 